\title{
Perbandingan Efektifitas Antara Monoterapi Empiris Seftazidime dan Sefepim pada Anak Leukemia Limfoblastik Akut dengan Demam Neutropenia
}

Filla Reviyani Suryaningrat, Aris Primadi, Alex Chairulfatah

Bagian Ilmu Kesehatan Anak Fakultas Kedokteran Universitas Padjadjaran/RSUP Dr. Dr. Hasan Sadikin, Bandung

Latar belakang. Demam neutropenia pada leukemia limfoblastik akut (LLA) termasuk kegawatan onkologi yang harus mendapatkan tatalaksana segera berupa pemberian antibiotik tanpa menunggu hasil kultur. Saat ini, seftazidim dan sefepim digunakan sebagai monoterapi empiris demam neutropenia di Divisi Hemato-Onkologi Rumah Sakit Hasan Sadikin. Namun, hingga saat ini, efektifitas kedua antibiotik tersebut tidak pernah dinilai. Tujuan. Studi ini bermaksud untuk membandingkan efektifitas seftazidim dan sefepim sebagai monoterapi empiris pada pasien demam neutropenia anak dengan LLA.

Metode. Uji acak terkendali dilakukan terhadap pasien LLA anak dengan demam neutropenia pada bulan Maret 2017 hingga Maret 2018 di Rumah sakit Dr Hasan Sadikin Bandung. Seftazidim dan sefepim diberikan secara konsekutif sebagai monoterapi empiris. Turunnya demam, peningkatan absolute neutophyl count (ANC) dan penurunan C-reactive protein (CRP) pada hari ke-3, 5, dan 7 digunakan sebagai parameter efektivitas terapi.

Hasil. Sebanyak 48 pasien mengikuti penelitian hingga selesai. Seftazidim dan sefepim diberikan masing-masing pada 28 dan 20 pasien. Tidak didapatkan perbedaan bermakna secara statistik pada usia, jenis kelamin dan keparahan penyakit pada kedua grup ( $\mathrm{p}=0,908, \mathrm{p}=0,251, \mathrm{p}=0,507)$. Pada kelompok seftazidim terjadi penurunan demam pada hari ke-2, 3-4, 5-6 and >7 ditemukan sebanyak 15 (53,6\%), 4 (14,3\%), 1 (3,6\%), 8 (28,6\%) pasien, sedangkan pada kelompok sefepim masing-masing ditemukan pada $12(60 \%), 4(20 \%), 0$, dan $4(20 \%)$ pasien ( $\mathrm{p}=0,638$, $\mathrm{p}=0,442$, $\mathrm{p}=0,583$ $\mathrm{p}=0,449)$. Nilai rata-rata ANC pada awal 315,4 (154,2) pada grup seftazidim dan 276,2 (292,3) pada grup sefepim ( $\mathrm{p}=0,778)$. Sebagian besar pasien pada kedua grup mencapai ANC $>500$ pada hari $5(x=773(1603,8)$ dan $x=840(979,8),(p=0,664)$. Nilai CRP awal mengalami sedikit peningkatan dari nilai normal, tidak berbeda signifikan secara statistik ( $x=8,80(6,28)$ CI 0,3-28,1 dan 13,62 (10,57) CI 0,5-35,3; $p=0,193)$. Nilai CRP menurun pada kedua grup pada hari ke-7 ( $\mathrm{x}=7,84(6,82)$, CI 0,5-25 dan 8,15 (9,39) CI 0,1-36,7; $\mathrm{p}=0,618)$

Kesimpulan. Penelitian ini menunjukan bahwa seftazidim dan sefepim memiliki efektifitas yang sama sebagai monoterapi empiris pada pasien LLA anak dengan demam neutropenia. Pemilihan antibiotik dengan mempertimbangkan ketersediaan obat, biaya, dan efek samping. Sari Pediatri 2019;21(2):81-8

Kata kunci: demam neutropenia, leukemia limfoblastik akut, sefepim, seftazidim, monoterapi

\section{Comparison of Effectiveness Between Ceftazidime and Cefepime as Empirical Monotherapy of Febrile Neutropenia in Children with Acute Lymphoblastic Leukemia}

Filla Reviyani Suryaningrat, Aris Primadi, Alex Chairulfatah

Background. Febrile neutropenia in ALL is an oncology emergency that requires rapid treatment in the form of antibiotics without waiting for blood culture result. At this time ceftazidime and cefepime are antibiotics use as empiric monotherapy in febrile neutropenia at Hasan Sadikin Hospital. Until now, the comparison of the effectivity of the two drugs as empirical monotherapy in febrile neutropenia is unknown.

Objective. This study aims to compare the effectiveness of ceftazidime and cefepime as empiric monotherapy of febrile neutropenia in children with ALL. Methods. A single-blind randomized clinical trial was conducted on pediatric ALL with febrile neutropenia admitted to pediatric ward or emergency room from March 2017 to March 2018. Ceftazidime and Cefepime were consecutively be given as empirical monotherapy on admission. Day of fever defervescent, the increase of absolute neutrophil count (ANC) and the decrease of C-reactive protein (CRP) on day 3, 5 and 7 were used to evaluate the effectivity of treatment.

Result. Forty-eight patients completed this study. Ceftazidime and cefepime were given in 28 and 20 patients respectively. No statistically different in age, gender and severity of illness in both group $(\mathrm{p}=0.908, \mathrm{p}=0.251, \mathrm{p}=0.507$ respectively). Ceftazidime defervescent of fever on day 2, 3-4, 5-6 and $>7$ were found in $15(53.6 \%), 4(14.3 \%), 1(3.6 \%), 8(28.6 \%)$ patients. Whereas in the cefepime group each was found in $12(60 \%), 4(20 \%), 0$, dan $4(20 \%)$ patients $(\mathrm{p}=0.638, \mathrm{p}=0.442, \mathrm{p}=0.583 \mathrm{p}=0.449$ respectively). The mean of ANC on admission was 315.4 (154.2) in ceftazidime group and 276.2 (292.3) in cefepime group ( $\mathrm{p}=0.778)$. Most patients in both group reached the ANC $>500$ on day $5(\mathrm{x}=773(1603.8)$ and $\mathrm{x}=840(979.8)$, $\mathrm{p}=0.664)$. The value of CRP on admission revealed slightly increase than normal value, no statistically significant defferent in both group $(x=8.80$ (6.28) CI $0.3-28.1$ vs 13.62 (10.57) CI $0.5-35.3 \mathrm{p}=0,193)$. The CRP value decreased in both group, no statistically significant difference in CRP on day 7 ( $\mathrm{x}=7.84$ (6.82), CI $0.5-25$ vs 8.15 (9.39) CI 0.1-36.7, $\mathrm{p}=0.618$ )

Conclusion. This study shows that both monotherapy ceftazidime and cefepime had similar effectivity as empirical antibiotic for pediatric acute lymphoblastic leukemia with febrile neutropenia. Need to consider aspects of costs, availability, side effects that may arise in the selection of antibiotics. Sari Pediatri 2019;21(2):81-8

Keywords: febrile neutropenia, acute lymphoblastic leukemia, cefepime, ceftazidime, monotherapy

Alamat korespondensi: Filla Reviyani Suryaningrat. Departemen Ilmu Kesehatan Anak Fakultas Kedokteran UNPAD Gedung Kenanga Lantai 3, Jl. Pasteur No.38, Pasteur, Sukajadi, Bandung, Jawa Barat 40161. Email: filla.reviyani@gmail.com 


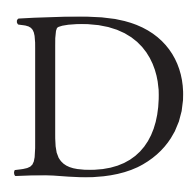
emam neutropenia adalah penyebab morbiditas dan mortalitas pada anak dengan keganasan. ${ }^{1-4}$ Angka kematian mencapai $11 \%$ pada pasien dengan keganasan hematologi. ${ }^{4}$ Demam neutropenia pada keganasan terjadi terutama pada pasien leukemia limfoblastik akut (LLA). Leukemia limfoblastik akut adalah keganasan yang paling umum didiagnosis pada anak $<15$ tahun dan menyumbang $78 \%$ dari semua leukemia pada masa anak. ${ }^{5}$ Data lain menunjukkan bahwa LLA terdiri dari 75\%-80\% dari semua leukemia yang didiagnosis pada anak. ${ }^{6}$

Neutropenia menghambat respons tubuh terhadap peradangan sehingga mengurangi tanda-tanda khas infeksi. ${ }^{7,8}$ Kemungkinan infeksi nosokomial meningkat ketika tubuh menjadi lebih lemah. Analisis kultur darah di Rumah Sakit Dr. Hasan Sadikin menunjukkan bahwa bakteri yang paling umum diidentifikasi adalah Staphylococcus hominis sp hominis dan Staphylococcus haemolyticus; diikuti oleh Escherichia coli dan Klebsiella pneumoniae sp pneumonia. ${ }^{9}$ Bakteri ini, umumnya, ditemukan di rumah sakit dan dapat menjadi sumber infeksi untuk pasien neutropenia. Menunda antibiotik dengan menunggu konfirmasi infeksi secara bakteriologis menyebabkan peningkatan mortalitas. ${ }^{10}$

Neutropenia meningkatkan kemungkinan pasien keganasan untuk menderita infeksi oleh bakteri Gram negatif. ${ }^{11}$ Berbagai penelitian melaporkan bahwa monoterapi lebih murah dan lebih sedikit menimbulkan efek toksisitas dibandingkan dengan terapi kombinasi. ${ }^{12}$ Paul $\mathrm{dkk}^{13}$ menunjukkan bahwa penggunaan $\beta$-laktam sebagai monoterapi sama efektif dengan kombinasi obat ini dengan aminoglikosida. Selain itu, penggunaan antibiotik yang berlebihan dapat meningkatkan risiko infeksi nosokomial, resistensi mikroba dan efek samping, serta meningkatkan biaya pengobatan. Sorensen ${ }^{14}$ melaporkan bahwa antibiotik oral (tanpa rawat inap) sama efektif dengan antibiotik intravena (dengan rawat inap) untuk pasien yang tepat dengan risiko yang lebih rendah. Saat ini, Infectious Diseases Society of America (IDSA) 2010 merekomendasikan penggunaan $\beta$-laktam antipseudomonal sebagai monoterapi termasuk sefepim, seftazidim, karbapenem, atau piperasilintazobaktam. ${ }^{3}$

Saat ini, sefepim dan seftazidim merupakan antiobiotik yang tersedia dan sesuai panduan sebagai monoterapi untuk demam neutropenia di Rumah Sakit Dr. Hasan Sadikin Bandung. Namun, belum ada penelitian tentang efektivitas kedua jenis antibiotik ini. Penelitian ini bertujuan untuk membandingkan efektivitas sefepim dan seftazidim sebagai monoterapi demam neutropenia pada pasien anak dengan LLA.

\section{Metode}

Penelitian dilaksanakan dari bulan Maret 2017 sampai dengan Maret 2018 dengan subyek penelitian anak pasien LLA di bawah 18 tahun yang mengalami demam neutropenia. Jumlah subjek penelitian dihitung melalui rumus untuk menguji perbedaan dua proporsi yang menghasilkan jumlah 48 anak, masing-masing 24 subjek penelitian untuk setiap kelompok penelitian. Tempat penelitian dilaksanakan di ruang rawat inap atau pasien yang berobat ke ruang emergensi Departemen Ilmu Kesehatan Anak RS Hasan Sadikin. Semua subyek penelitian mendapat monoterapi seftazidim atau sefepim yang alokasi pemberiannya ditentukan melalui random permutation sampling. Penelitian ini merupakan penelitian single blind, pasien tidak mengetahui obat apa yang diberikan. Untuk menilai efektifitas pengobatan dilakukan dengan menilai parameter penurunan demam, jumlah peningkatan absolute neutrophyl count (ANC) dan penurunan kadar $C$-reactive protein (CRP) pada hari ke-3, 5, dan 7. Kultur darah dilakukan pada semua subyek penelitian sebelum mendapatkan antibiotik. Uji statistik dilakukan dengan uji Kai Kuadrat (chisquare) dan uji Mann Whitney untuk data dengan distribusi tidak merata. Perbedaan bermakna jika didapatkan nilai $\mathrm{p}<0,05$. Data dianalisis menggunakan SPSS versi 15. Semua subjek dan orangtua/wali diberi penjelasan mengenai prosedur penelitian dan bila setuju diikutsertakan dalam penelitian dengan menandatangani lembar informed consent. Penelitian ini telah disetujui komite etik RS. Hasan Sadikin.

Demam neutropenia didefinisikan sebagai hasil pengukuran suhu tubuh per oral $\geq 38,3 \mathrm{C}$ atau $\geq 38,0 \mathrm{C}$ yang bertahan selama 1 jam, disertai penurunan ANC melebihi standar deviasi di bawah 2 rerata normal. ${ }^{8}$ Selain itu, neutropenia juga didefinisikan sebagai ANC darah turun di bawah $500 \mathrm{sel} / \mathrm{mm}$ atau diduga akan turun dalam 48 jam berikutnya dan menyebabkan tubuh dalam keadaan rentan terhadap infeksi. ${ }^{3,11}$

Tingkat keparahan LLA dinilai menurut National Cancer Institute (NCI), yaitu standar risk (SR) dan high risk (HR). ${ }^{15-17}$ Standard risk apabila leukosit kurang dari 
50,000/ $\mu \mathrm{L}$, usia 1-10 tahun, serta tidak terdapat tandatanda risiko tinggi. High risk adalah leukosit 50,000/ $\mu \mathrm{L}$ atau lebih, usia kurang dari 1 tahun atau lebih dari 10 tahun, massa mediastinum $>2 / 3$ diameter rongga thoraks, lebih dari 1000 blast $/ \mathrm{mm}^{3}$ pada pemeriksaan darah tepi setelah 1 minggu mulai terapi, terdapat 5 sel leukemia di serebrospinal (leukemia serebral, meningeal), didapatkan sel blast pada pungsi lumbal.

\section{Hasil}

Sebanyak 28 dan 20 subjek penelitian mendapat pengobatan monoterapi seftazidim dan sefepim. Ketersediaan sefepim pada bulan-bulan terakhir penelitian menyebabkan jumlah subjek penelitian pada kelompok ini sedikit lebih rendah dibanding kelompok seftazidim. Karakteristik subjek penelitian pada kedua kelompok meliputi usia anak, jenis kelamin, dan tingkat keparahan LLA tertera pada Tabel 1.
Dari 48 subjek didapatkan rata-rata usia anak yang mendapat seftazidim 6,9 tahun dengan rentang 2-15 tahun dan rata-rata usia anak yang mendapat sefepim 7,2 tahun rentang 1-17 tahun. Karakteristik usia pada kedua kelompok secara statistik tidak berbeda bermakna $(p=0,905)$. Tabel 1 juga menunjukkan bahwa jenis kelamin laki-laki dan perempuan pada kedua kelompok tidak memiliki perbedaan signifikan $(\mathrm{p}=0,251)$. Hal yang sama ditemukan pula pada kategori derajat keganasan $(\mathrm{p}<0,507)$. Dengan demikian disimpulkan bahwa kedua kelompok sampel menunjukkan homogenitas sehingga dinilai layak untuk diperbandingkan.

Sebagian besar subyek dari kedua kelompok mengalami penurunan suhu menjadi normal atau $<37,5^{\circ} \mathrm{C}$ pada hari ke-1 dan 2 setelah diberikan antibiotik. Tidak ada perbedaan signifikan diantara hari penurunan suhu dari kedua kelompok subjek. Pada hari ke-1-2 ( $\mathrm{p}=0,638), 3-4(\mathrm{p}=0,442), 5-6(\mathrm{p}=0,583)$. Ditemukan $8(28,6 \%)$ pada kelompok seftazidim dan

Tabel 1. Karakteristik pasien

\begin{tabular}{|c|c|c|c|}
\hline \multirow[b]{2}{*}{ Karakteristik } & \multicolumn{2}{|c|}{ Pengobatan } & \multirow[b]{2}{*}{ Nilai $\mathrm{p}^{*}$} \\
\hline & $\begin{array}{l}\text { Seftazidim } \\
\quad(n=28)\end{array}$ & $\begin{array}{l}\text { Sefepim } \\
(\mathrm{n}=20)\end{array}$ & \\
\hline Usia (tahun) & & & 0,908 \\
\hline$<5$ & 11 & 6 & \\
\hline $5-9$ & 10 & 9 & \\
\hline $10-14$ & 4 & 3 & \\
\hline$\geq 15$ & 3 & 2 & \\
\hline Rata-rata $(\mathrm{SD})$ & $6,9(4,2)$ & $7,2(4,6)$ & \\
\hline Rentang & $2-15$ & $1-17$ & \\
\hline Jenis kelamin & & & 0,251 \\
\hline Laki-laki & 15 & 14 & \\
\hline Perempuan & 13 & 6 & \\
\hline \multicolumn{4}{|l|}{ Kategori derajat keganasan : } \\
\hline Standard risk (SR) & 11 & 6 & 0,507 \\
\hline High risk (HR) & 17 & 14 & \\
\hline
\end{tabular}

*) berdasarkan uji Chi-kuadrat; Bermakna jika $\mathrm{p}<0,05$.

Tabel 2. Gambaran hilangnya demam

\begin{tabular}{lccc}
\hline \multirow{2}{*}{ Hilangnya demam (hari ke-) } & \multicolumn{2}{c}{ Pengobatan } & \\
\cline { 2 - 3 } & $\begin{array}{c}\text { Seftazidim } \\
(\mathrm{n}=28)\end{array}$ & $\begin{array}{c}\text { Sefepim } \\
(\mathrm{n}=20)\end{array}$ & Nilai p $)^{*}$ \\
\hline $1-2$ & $15(53,6 \%)$ & $12(60 \%)$ & 0,638 \\
$3-4$ & $4(14,3 \%)$ & $4(20 \%)$ & 0,442 \\
$5-6$ & $1(3,6 \%)$ & 0 & 0,583 \\
$>7$ & $8(28,6 \%)$ & $4(20 \%)$ & 0,449 \\
\hline
\end{tabular}

hilang demam jika suhu $<37,5^{\circ} \mathrm{C}$; *) Uji chi-square 
$4(20 \%)$ pada kelompok sefepim yang tidak mengalami penurunan suhu menjadi normal setelah 7 hari terapi ( $\mathrm{p}=0,449)$ (tabel 2).

Rata-rata nilai ANC saat awal dirawat pada kelompok seftazidim $315(154,2)$ dan 276,2 $(292,3)$ pada kelompok sefepim $(\mathrm{p}=0,778)$. Rata-rata nilai ANC di atas 500 terjadi pada pemantauan hari ke- 5 pada kedua kelompok subjek, dengan nilai rata-rata $773,0(1603,8)$ pada kelompok seftazidim dan 840,1 $(979,8)$ pada kelompok sefepim $(\mathrm{p}=0,664)$ (Tabel 3).

Tabel 3. Perbandingan ANC

\begin{tabular}{|c|c|c|c|}
\hline \multirow[b]{2}{*}{ ANC } & \multicolumn{2}{|c|}{ Pengobatan } & \multirow[t]{2}{*}{ Nilai $\left.{ }^{*}\right)$} \\
\hline & $\begin{array}{l}\text { Seftazidim } \\
(\mathrm{n}=28)\end{array}$ & $\begin{array}{c}\text { Sefepim } \\
(\mathrm{n}=20)\end{array}$ & \\
\hline Hari ke-1 : & & & 0,778 \\
\hline Rata-rata (SD) & $315,4(154,2)$ & $276,2(292,3)$ & \\
\hline Median & 188 & 115,5 & \\
\hline Rentang & $0-589$ & $0-924$ & \\
\hline \multicolumn{4}{|l|}{ Hari ke-3 : } \\
\hline Rata-rata (SD) & $501,8(1021,7)$ & $408,0(415,2)$ & 0,746 \\
\hline Median & 227,5 & 269 & \\
\hline Rentang & $16-5300$ & $2-1284$ & \\
\hline \multicolumn{4}{|l|}{ Hari ke-5: } \\
\hline Rata-rata (SD) & $773,0(1603,8)$ & $840,1(979,8)$ & \\
\hline Median & 272 & 412,4 & 0,664 \\
\hline Rentang & $24-7620$ & $10-3687$ & \\
\hline \multicolumn{4}{|l|}{ Hari ke-7 : } \\
\hline Rata-rata & $810,6(1280,1)$ & $1858,5(3758,5)$ & \\
\hline (SD) & 320,4 & 371 & \\
\hline Median & $30-4200$ & $6-15658$ & 0,692 \\
\hline Rentang & & & \\
\hline
\end{tabular}

*) berdasarkan uji Mann-Whitney; Bermakna jika $\mathrm{p}<0,05$

Tabel 4. Perbandingan CRP

\begin{tabular}{lccc}
\hline CRP & \multicolumn{2}{c}{ Pengobatan } & \multirow{2}{*}{ Nilai p $^{*}$} \\
\cline { 2 - 3 } & $\begin{array}{c}\text { Seftazidim } \\
(\mathrm{n}=28)\end{array}$ & $\begin{array}{c}\text { Sefepim } \\
(\mathrm{n}=20)\end{array}$ & 0,193 \\
\hline Hari ke-1 : & $8,80(6,28)$ & $13,62(10,57)$ & \\
Rata-rata (SD) & 8,30 & 10,35 & \\
Median & $0,3-28,1$ & $0,5-35,3$ & \multirow{2}{*}{0,237} \\
Rentang & & & \\
Rari ke-3: & $7,61(6,71)$ & $13,34(16,56)$ & \\
Median & 5,10 & 10,20 & 0,618 \\
Rentang & $0,2-30,5$ & $0,2-75,0$ & \\
Hari ke-5: & & & \\
Rata-rata (SD) & $7,32(6,58)$ & $9,05(8,39)$ & 0,618 \\
Median & 5,4 & 8,15 & \\
Rentang & $0,1-25,0$ & $0,1-32,4$ & \\
Hari ke-7: & & & \\
Rata-rata (SD) & $7,84(6,82)$ & $8,15(9,39)$ & \\
$\quad$ Median & 7,20 & 6,70 & \\
Rentang & $0,5-25,0$ & $0,1-36,7$ & \\
\hline
\end{tabular}

Keterangan : *) berdasarkan uji Mann-Whitney; Bermakna jika $\mathrm{p}<0,05$. 
Filla Reviyani Suryaningrat dkk: Perbandingan efektifitas antara monoterapi empiris seftazidime dan sefepim pada LLA dengan demam neutropenia

Tabel 5. Hasil kultur bakteri dan sensitifitas antibiotik

\begin{tabular}{lc}
\hline Parameter & $\mathrm{n}(\%)$ \\
\hline Kultur mikroba & \\
\hline No Growth & $37(77,1)$ \\
Eschericia coli & $2(4,2)$ \\
Streptococcus dysgalactieae & $2(4,2)$ \\
Acinetobacter sp. & $1(2,1)$ \\
Candida Albicans & $1(2,1)$ \\
Staphylococcus sp coagulase resistant & $1(2,1)$ \\
Staphylococcus hominis (Methicillin resistant, coagulase resistant & $1(2,1)$ \\
Micrococcus sp & $1(2,1)$ \\
Pseudomonas aeruginosa & $1(2,1)$ \\
\hline Sensitivitas antibiotik di antara sampel yang dikultur-positif & \\
\hline Penisilin (dan derivatif) sensitif & $6(54,5)$ \\
Karbapenem sensitif & $5(45,5)$ \\
Sefalosporin sensitif & \\
\multicolumn{1}{c}{ Seftazidim sensitif } & $6(54,5)$ \\
$\quad$ Sefepime sensitif & $6(54,5)$ \\
Aminoglikosida sensitif & $2(18,2)$ \\
\hline
\end{tabular}

Nilai rata-rata CRP pada saat diagnosis lebih tinggi dari normal, yaitu 8,8 $(6,28)$ pada kelompok seftazidim dan 13,62 (10,57) pada kelompok sefepim ( $\mathrm{p}=0,193)$. Pada pemantauan selanjutnya tidak ditemukan perbedaan bermakna dari penurunan CRP di antara kedua kelompok pada hari ke-3, 5, dan 7 (Tabel 4). Rata-rata nilai CRP pada kedua kelompok meningkat, tetapi dengan kadar tersebut masih dimungkinkan oleh penyebab non bakteri. Kemungkinan ini didukung oleh hasil pemeriksaan kultur darah.

Tabel 5 menunjukkan bahwa sebagian besar $(77,1 \%)$ tidak ditemukan pertumbuhan bakteri pada biakan. Bakteri patogen seperti Actinobacter sp ditemukan pada kelompok seftazidim dan Pseudomonas aeruginosa ditemukan pada kelompok sefepim. Kedua kelompok menunjukkan penurunan suhu tubuh menjadi normal pada hari ke-5 pemberian antibiotik.

\section{Pembahasan}

Pada saat ini, berdasarkan ketersediaan, sefepim dan seftazidim adalah antibiotik yang digunakan sebagai monoterapi empiris demam neutropenia di Divisi Hemato-Onkologi Kelompok Staf Medis (KSM) Ilmu Kesehatan Anak RSUP Dr. Hasan Sadikin, Bandung. Namun begitu, efektivitas di antara kedua obat tersebut belum pernah dibandingkan. Seftazidim, sefalosporin generasi ketiga dan sefepim, sefalosporin generasi keempat merupakan antibiotik yang dipakai dalam pedoman monoterapi empiris untuk demam neutropenia di beberapa negara di Eropa. ${ }^{18}$

Sebuah studi meta analisis yang dilakukan oleh Horita $\mathrm{dkk}^{19}$ pada pasien demam neutropenia didapatkan bahwa sefepim memiliki efektifitas lebih tinggi daripada seftazidim dibandingkan dengan imipenem sebagai komparator yang direkomendasikan, tetapi dalam subgrup pasien anak, tidak didapatkan perbedaan yang bermakna. Meta analisis dari Cochran ${ }^{20}$ menyebutkan bahwa sefepim dan seftazidim memiliki efikasi dan efektifitas yang serupa. Penelitian IDSA dalam metaanalisis mereka menemukan bahwa administrasi sefepim mungkin berhubungan dengan peningkatan mortalitas di antara pasien ALL dengan demam neutropenia, ${ }^{21}$ tetapi penelitian Food and Drug Administration Amerika Serikat menunjukkan bahwa peningkatan mortalitas tidak berkaitan dengan sefepim. ${ }^{22}$ Penelitian lain juga menemukan sefepim sama efektif dan amannya dengan piperasilin/ tazobaktam, dan sefozopran pada anak-anak dengan demam neutropenia. Dengan demikian, sefepim dapat direkomendasikan sebagai terapi empiris untuk populasi pediatri. . $^{23,24}$

Terapi inisial untuk demam neutropenia pada anak dipengaruhi oleh berbagai faktor, bergantung dari 
presentasi klinis, karakteristik pasien, perkembangan infrastruktur kesehatan, ketersediaan antibiotik, dan pola resistensi kuman lokal. ${ }^{18,25}$ Pada penelitian skala besar yang mendata seluruh anak yang menjalani terapi demam neutropenia tahun 1995-2002 di Amerika Serikat, pasien demam neutropenia kelompok umur bayi di bawah satu tahun memiliki risiko mortalitas yang lebih tinggi. ${ }^{26}$ Analisis univariat yang dilakukan oleh Rondinelli $\mathrm{dkk}^{27}$ menunjukkan bahwa beberapa faktor berkaitan dengan komplikasi infeksi akut pada pasien demam neutropenia, seperti jenis kelamin perempuan, umur di bawah 5 tahun, dan keparahan penyakit (hemoglobin $<7 \mathrm{~g} / \mathrm{dL}$, infeksi fokal dan infeksi saluran pernafasan atas). Pada penelitian kami tidak didapatkan perbedaan yang bermakna antara keganasan penyakit, usia dan jenis kelamin pada kedua kelompok sampel sehingga dinilai layak untuk diperbandingkan.

European Conference on Infections in Leukemia (ECIL) tahun 2011 menyarankan pemberian terapi empiris menggunakan antibiotik spektrum luas hingga didapatkan peningkatan neutrofil dengan 2 hari tanpa demam atau setidaknya 7 hari tanpa demam dengan neutropenia yang persisten. ${ }^{18}$ Pada penelitian kami, hilangnya demam $>50 \%$ terjadi dalam 2 hari pemberian antibiotik, dan tidak didapatkan perbedaan bermakna di antara kedua kelompok.

Dilihat dari jumlah neutrofil, kedua kelompok memiliki ANC $<500 / \mathrm{mm}^{3}$ pada saat dirawat, tetapi tidak ada perbedaan bermakna dari kedua kelompok. Penelitian ini menunjukkan bahwa terjadi peningkatan ANC dari kedua kelompok pada hari ke-3 (setelah 2 hari pengobatan) dan kedua kelompok telah memiliki rata-rata ANC $>500 \mathrm{sel} / \mathrm{mm}^{3}$ pada hari ke-5. Peningkatan ANC pada hari pengobatan tersebut tidak berbeda bermakna pada kedua kelompok.

$C$-reactive protein merupakan salah satu petanda infeksi bila terjadi keterlambatan normalisasi dalam 3-7 hari pertama. Hal tersebut menunjukkan bahwa terapi antibiotik empiris tidak tepat. ${ }^{28}$ Pada penelitian kami, kadar CRP kedua kelompok meningkat saat masuk rumah sakit. Nilai CRP yang rendah saat masuk perawatan dan kemudian menurun selama perawatan mungkin disebabkan demam yang terjadi disebabkan oleh virus. Hal tersebut diperkuat dengan hasil kultur yang menunjukkan tidak ditemukannya pertumbuhan bakteri pada $77,1 \%$ pasien. Hakim $\mathrm{dkk}^{25}$ menemukan sekitar 34\% penyebab demam pada pasien demam neutropenia pediatri adalah virus. Teranishi $\mathrm{dkk}^{29}$ juga menemukan bahwa penggunaan polymerase chain reaction (PCR) real-time memiliki kemampuan mendeteksi mikrobiologi yang lebih baik pada orang dewasa dan anak dengan demam neutropenia. Karena alasan biaya, PCR real-time tidak dilakukan.

Pada penelitian kami, bakteri patogen Acinatobacter $S p$ dan Pseudomonas aeruginosa ditemukan masingmasing pada 1 pasien. Penelitian Adrizain ${ }^{29}$ di rumah sakit yang sama pada tahun 2015 menemukan prevalensi kedua bakteri tersebut masing-masing 5 dan 20 pasien.

Dilihat dari segi pembayaran, seftazidim lebih murah dibanding sefepim untuk terapi demam neutropenia. Aspek biaya dapat memengaruhi ketersediaan obat. Penelitian kami menunjukkan bahwa pada bulan terakhir penelitian, sefepim tidak tersedia sehingga jumlah subjek penelitian yang mendapat obat ini sedikit lebih rendah dibandingkan dengan yang mendapat seftazidim.

Penelitian kami memiliki beberapa keterbatasan, yaitu ukuran sampel yang kecil dan durasi pengamatan yang pendek, serta hasil isolasi bakteri yang rendah. Penelitian kami juga tidak mendokumentasikan efek samping pada pasien yang menerima kedua antibiotik. Diperlukan suatu uji acak terkendali lebih lanjut pada pasien demam neutropenia dengan jumlah isolasi bakteri yang tinggi dan durasi penelitian yang lebih lama terutama untuk menilai efek samping pengobatan.

\section{Kesimpulan}

Berdasarkan gejala penurunan demam, peningkatan ANC dan penurunan CRP, seftazidim dan sefepim cukup efektif sebagai monoterapi empiris pada pasien ALL yang mengalami demam neutropenia. Perlu dipertimbangkan aspek biaya, ketersediaan, efek samping yang mungkin timbul dalam pemilihan antibiotik.

\section{Daftar pustaka}

1. Tamura K. Clinical guidelines for the management of neutropenic patients with unexplained fever in Japan: validation by the Japan Febrile Neutropenia Study Group. Int J Antimicrob Agents 2005;26:123-7.

2. Sudewi NP, Tumbelaka AR, Windiastuti E. Kejadian demam neutropenia pada keganasan. Sari Pediatri 2007;8:68-72. 
Filla Reviyani Suryaningrat dkk: Perbandingan efektifitas antara monoterapi empiris seftazidime dan sefepim pada LLA dengan demam neutropenia

3. Freifeld AG, Bow EJ, Sepkowitz KA, Boeckh MJ, Ito JI, Mullen CA, dkk. Clinical practice guideline for the use of antimicrobial agents in neutropenic patients with cancer: 2010 update by the Infectious Diseases Society of America. Clin Infect Dis 2011;52:56-93.

4. De Naurois J, Novitzky-Basso I, Gill MJ, Marti FM, Cullen $\mathrm{MH}$, Roila F, dkk. Management of febrile neutropenia: ESMO clinical practice guidelines. Ann Oncol 2010;21:252--6.

5. Yeoh AEJ, Tan D, Li C-K, Hori H, Tse E, Pui C-H. Management of adult and paediatric acute lymphoblastic leukaemia in Asia: resource-stratified guidelines from the Asian Oncology Summit 2013. Lancet Oncol 2013;14:508-523.

6. Sousa DWL de, Ferreira FV de A, Félix FHC, Lopes MV de O. Acute lymphoblastic leukemia in children and adolescents: prognostic factors and analysis of survival. Rev Bras Hematol Hemoter 2015;37:223-9.

7. Kannangara S. Management of febrile neutropenia. Community Oncol 2006;9:585-91.

8. Shrestha PN, Sah K, Rana R. Emperical oral antibiotic therapy for children with low risk febrile neutropenia during cancer chemotherapy. J Nepal Paediatr Soc 2009;29:22-5.

9. Tim PPRA-SMF/Departemen Patologi Klinik RSUP Dr. Hasan Sadikin Bandung. Peta bakteri dan kepekaannya terhadap berbagai antibiotika di Rumah Sakit Umum Pusat Dr. Hasan Sadikin Bandung. Parwati I, Sugianli AK, penyunting. Bandung: Departemen Patologi Klinik, Universitas Padjadjaran; 2015.

10. Amundsen EK, Urdal P, Hagve T-A, Holthe MR, Henriksson CE. Absolute neutrophil counts from automated hematology instruments are accurate and precise even at very low levels. Am J Clin Pathol 2012;137:862-9.

11. Sharma A, Lokeshwar N. Febrile neutropenia in haematological malignancies. J Postgrad Med 2005;51:42.

12. Agaoglu L, Devecioglu O, Anak S, Karakas Z, Yalman N, Biner B, dkk. Cost-effectiveness of cefepime+ netilmicin or ceftazidime+ amikacin or meropenem monotherapy in febrile neutropenic children with malignancy in Turkey. J Chem Taylor \& Francis 2001;13:281-7.

13. Paul M, Benuri-Silbiger I, Soares-Weiser K, Leibovici L. Beta lactam monotherapy versus beta lactam-aminoglycoside combination therapy for sepsis in immunocompetent patients: systematic review and meta-analysis of randomised trials. BMJ 2004;328:668.

14. Carstensen M, Sorensen JB. Outpatient management of febrile neutropenia: time to revise the present treatment strategy. J Support Oncol 2008;6:199-208.

15. Smith M, Arthur D, Camitta B, Carroll AJ, Crist W, Gaynon P, dkk. Uniform approach to risk classification and treatment assignment for children with acute lymphoblastic leukemia.
J Clin Oncol 1996;14:18-24.

16. Pui C-H, Robison LL, Look AT. Acute lymphoblastic leukaemia. Lancet 2008;371:1030-43.

17. Schultz KR, Pullen DJ, Sather HN, Shuster JJ, Devidas M, Borowitz MJ, dkk. Risk-and response-based classification of childhood B-precursor acute lymphoblastic leukemia: a combined analysis of prognostic markers from the Pediatric Oncology Group (POG) and Children's Cancer Group (CCG). Blood. Am Soc Hematology 2007;109:926-35.

18. Averbuch D, Orasch C, Cordonnier C, Livermore DM, Mikulska M, Viscoli C, dkk. European guidelines for empirical antibacterial therapy for febrile neutropenic patients in the era of growing resistance: summary of the 2011 4th European Conference on Infections in Leukemia. Haematologica 2013;98:1826-35.

19. Horita N, Shibata Y, Watanabe H, Namkoong H, Kaneko T. Comparison of antipseudomonal $\beta$-lactams for febrile neutropenia empiric therapy: systematic review and network meta-analysis. Clin Microbiol Infect 2017;23:723-9.

20. Paul M, Yahav D, Bivas A, Fraser A, Leibovici L. Antipseudomonal beta-lactams for the initial, empirical, treatment of febrile neutropenia: comparison of beta-lactams. Cochrane Database Syst Rev 2010; 10:CD005197. doi: 10.1002/14651858.CD005197.pub3.

21. Andreatos N, Flokas ME, Apostolopoulou A, Alevizakos M, Mylonakis E. The dose-dependent efficacy of cefepime in the empiric management of febrile neutropenia: a systematic review and meta-analysis. Open Forum Infect Dis 2017; 24:ofx113. doi: 10.1093/ofid/ofx113.

22. Kim PW, Wu Y, Cooper C, Rochester G, Valappil T, Wang Y, dkk. Meta-analysis of a possible signal of increased mortality associated with cefepime use. Clin Infect Dis 2010;51:381-9.

23. Sano H, Kobayashi R, Suzuki D, Kishimoto K, Yasuda K, Kobayashi K. Comparison between piperacillin/tazobactam and cefepime monotherapies as an empirical therapy for febrile neutropenia in children with hematological and malignant disorders: a prospective, randomized study. Pediatr Blood Cancer 2015;62:356-8.

24. Sarashina T, Kobayashi R, Yoshida M, Toriumi N, Suzuki D, Sano H, dkk. A randomized trial of cefozopran versus cefepime as empirical antibiotic treatment of febrile neutropenia in pediatric cancer patients. Pediatr Blood Cancer 2014;61:1992-5.

25. Hakim H, Flynn PM, Knapp KM, Srivastava DK, Gaur A. Etiology and clinical course of febrile neutropenia in children with cancer. J Pediatr Hematol Oncol 2009;31:623-9.

26. Basu SK, Fernandez ID, Fisher SG, Asselin BL, Lyman GH. Length of stay and mortality associated with febrile neutropenia among children with cancer. J Clin Oncol 2005;23:7958-66. 
Filla Reviyani Suryaningrat dkk: Perbandingan efektifitas antara monoterapi empiris seftazidime dan sefepim pada LLA dengan demam neutropenia

27. Rondinelli PIP, Ribeiro K de CB, de Camargo B. A proposed score for predicting severe infection complications in children with chemotherapy-induced febrile neutropenia. J Pediatr Hematol Oncol 2006;28:665-70.

28. Bruns AH, Oosterheert JJ, Hak E, Hoepelman AI. Usefulness of consecutive C-reactive protein measurements in follow-up of severe community-acquired pneumonia. Rev Port Pneumol 2009;15:129-32.

29. Teranishi H, Ohzono N, Inamura N, Kato A, Wakabayashi T, Akaike H, dkk. Detection of bacteria and fungi in blood of patients with febrile neutropenia by real-time PCR with universal primers and probes. J Infect Chem 2015;21:189-93. 